\title{
Influence of integrated watershed-scale agricultural conservation practices on lake water quality
}

\author{
R.E. Lizotte, Jr., S.S. Knight, M.A. Locke, and R.L. Bingner
}

\begin{abstract}
Watershed-scale management efforts to improve conservation of water resources in agricultural watersheds depend upon the effectiveness of integrated multiple agricultural best management practices (BMPs). To more comprehensively assess the effectiveness of combined BMPs on water quality requires large-scale, long-term ( $>10$ year) studies measuring key water quality parameters. One such suite of critical water quality parameters includes water clarity, total suspended solids (TSS), and total dissolved solids (TDS). To address this, Beasley Lake, a 25 ha $(62 \mathrm{ac})$ oxbow lake located in a 915 ha $(2,261 \mathrm{ac})$ watershed of intensive row crop agricultural activity, was studied. The lake was sediment impaired when monitoring was initiated in 1995 and was a candidate to assess the effectiveness of watershed-wide BMPs on lake water clarity (as Secchi depth), TSS concentrations, and TDS. A variety of BMPs within row crop fields, at field edges throughout the watershed, and enrollment of 112 ha (277 ac) into the Conservation Reserve Program (CRP) between 1997 to 2006 focused on reducing soil erosion and concomitant sediment runoff. Selected parameters were measured approximately biweekly from 1996 to 2009. During this 14-year period, changes in row crop management and BMP implementations and alterations were observed and recorded in conjunction with targeted water quality parameters. While annual improvement in water quality occurred, distinct seasonal effects were noticeable. Observed changes in water clarity and TSS concentrations were greatest during spring and least in winter in association with increased BMPs, vegetated buffer strips west of the lake, and CRP north of the lake. Observed decreases in TDS concentrations were greatest during summer and fall in association with implemented CRP north of the lake. Reductions in spring TSS by $>60 \%$ often directly increased spring water clarity by $>100 \%$. Results of this study indicate clear improvement in lake water quality with watershed-wide implementation of integrated multiple agricultural BMPs, and these improvements, manifested most strongly during spring, will assist to promote a healthy, sustainable lake ecosystem.
\end{abstract}

Key words: best management practices-oxbow lake-Secchi depth-total dissolved solids — total suspended solids

Intensive row crop agriculture under conventional farming practices utilizes most available arable land. While necessary to feed and clothe a continually growing human population, these practices can often lead to significant soil erosion (Bennett and Chapline 1928) and surface runoff during rainfall events that produce increased loads of suspended sediment and dissolved solids, and decrease water clarity (Dodds and Whiles 2004; Renwick et al. 2008). Despite decades of research and considerable efforts to mitigate suspended sediment loading, sus- through declines in primary productivity via light limitation (Cooper and Lipe 1992; Cooper 1993; Devlin et al. 2008; Donahue and Molinos 2009), cascading through the food web to primary consumers and top predators and contributing to ecologically unsustainable lake systems (Henley et al. 2000; Sutherland and Meyer 2007; Bilotta and Brazier 2008). In 2000, the US National Water Quality Inventory reported that agricultural nonpoint source pollution was the greatest source of water quality impacts on surveyed lakes and rivers in the United States (USEPA 2005). A national need was recognized to document the efficacy of conservation best management practices (BMPs) used in maintaining and enhancing water resources. In 2003, the Conservation Effects Assessment Project (CEAP) was initiated to provide an empirical basis for this assessment at the watershed scale (Karlen 2008). Beasley Lake, an agriculturally impacted oxbow lake located in the Lower Mississippi River Alluvial Plain (i.e., the Delta), was chosen as one of 14 study watersheds included in CEAP. The rationale for this included a long-term extensive database (eight years) already available by 2003 on the understanding and contributions of multiple integrated BMPs from farm plot to watershed scales (Cullum et al. 2006; Zablotowicz et al. 2006; Zablotowicz et al. 2010).

As part of the national CEAP assessment, this study documents the effectiveness of watershed-wide agricultural conservation BMPs on lake water quality. The current study presents the evolution of multiple, integrated BMP implementation within the Beasley Lake Watershed and concomitant changes in lake water clarity (as Secchi depth), suspended sediment, and dissolved solids loads during a 14-year monitoring period (1996 to 2009). The resulting database provides critically important watershed-wide comprehensive empirical links between multiple integrated BMPs and lake water quality improvement and sustainability.

most pernicious pollutants and a significa cause of water quality impairment globally. Suspended sediment has long been known to cause problems in physical terms through reduced storage capacity in man-made reservoirs (Robinson 1971). Excessive suspended sediments also increase rates of lake senescence (Cole 1983) and act as carriers (sorption sites) for other pollutants such as nutrients and pesticides (Cooper and Lipe 1992). Suspended sediment can also directly lead to ecological and aesthetic degradation
Richard E. Lizotte, Jr. is an ecologist, Scott S. Knight is an ecologist, Martin A. Locke is a soil scientist, and Ronald L. Bingner is an agricultural engineer at the Water Quality and Ecology Research Unit, National Sedimentation Laboratory, USDA Agricultural Research Service, Oxford, Mississippi. 


\section{Materials and Methods}

Watershed Site Description. The study watershed, Beasley Lake, is located in Sunflower County, Mississippi, United States, latitude $33^{\circ} 24^{\prime} 15^{\prime \prime} \mathrm{N}$, longitude $90^{\circ} 40^{\prime} 05^{\prime \prime} \mathrm{W}$ (figure 1). Drainage area for the watershed is approximately 915 ha $(2,261 \mathrm{ac})$ with a lake surface area of approximately 25 to 30 ha (61 to $30 \mathrm{ac})$. Approximately $150 \mathrm{ha}(370 \mathrm{ac})$ of the watershed are nonarable riparian wetland with bottomland hardwood forest and herbaceous riparian vegetation. Approximately 722 ha $(1,784 \mathrm{ac})$ of arable land have been in row crop production with primarily cotton (Gossypium hirsutum L.), soybeans (Glycine $\max$ L.), and corn (Zea mays L.), and occasionally milo (Sorghum bicolor L. [Moench]) throughout the 14-year study period (table 1). During this monitoring period, a total of four major independent BMPs (encompassing $>0.5 \%$ of the arable land) were implemented. Prior to 1996, about 2.9 ha $(7.1 \mathrm{ac})$ of vegetated buffer were already established along the westernmost lake shoreline (figure 1). In 1996, about 2.7 ha $(6.7 \mathrm{ac})$ of a structural edge-of-field BMP were implemented that incorporated vegetative filter strips comprised of switchgrass (Panicum virgatum L.) or fescue (Festuca arundinacea [Schreb.]), and in 2001 an additional 3.4 ha $(8.3 \mathrm{ac})$ were implemented that incorporated vegetative filter strips comprised of bahia grass (Paspalum notatum Flugge) (Locke 2004; Locke et al. 2008) (figure 1). This early structural BMP was implemented to reduce suspended sediment loads and accompanying contaminants (e.g., phosphorus $[\mathrm{P}]$ and pesticides) from entering the lake. A structural management practice that was implemented in 1996 included drainage culverts positioned at low elevations within subdrainage areas. Some of these drainage pipes were modified with slotted board risers at the culvert inlet directly upstream from the sampling point, and during fallow periods or when heavy runoff was anticipated, wooden boards were inserted into the slots to slow runoff flow rate entering the pipe. Later, after settling of suspended sediment, the boards were removed. In 2001 to 2002, a cultural BMP was implemented, conservation tillage management for cotton and soybeans, which encompassed much of the arable portions of the watershed (table 1). From 2002 to 2004, 2006, and 2008 to 2009 , conservation tillage soybeans were the primary row crop ( $52 \%$ to $84 \%$ ) (table 1). From 2003 to 2004, approximately

\section{Figure 1}

Map of Beasley Lake Watershed showing locations of water quality sampling sites and locations and boundaries of the following best management practices: vegetated buffer strips, Conservation Reserve Program, and quail (Colinus virginianus) habitat buffer.

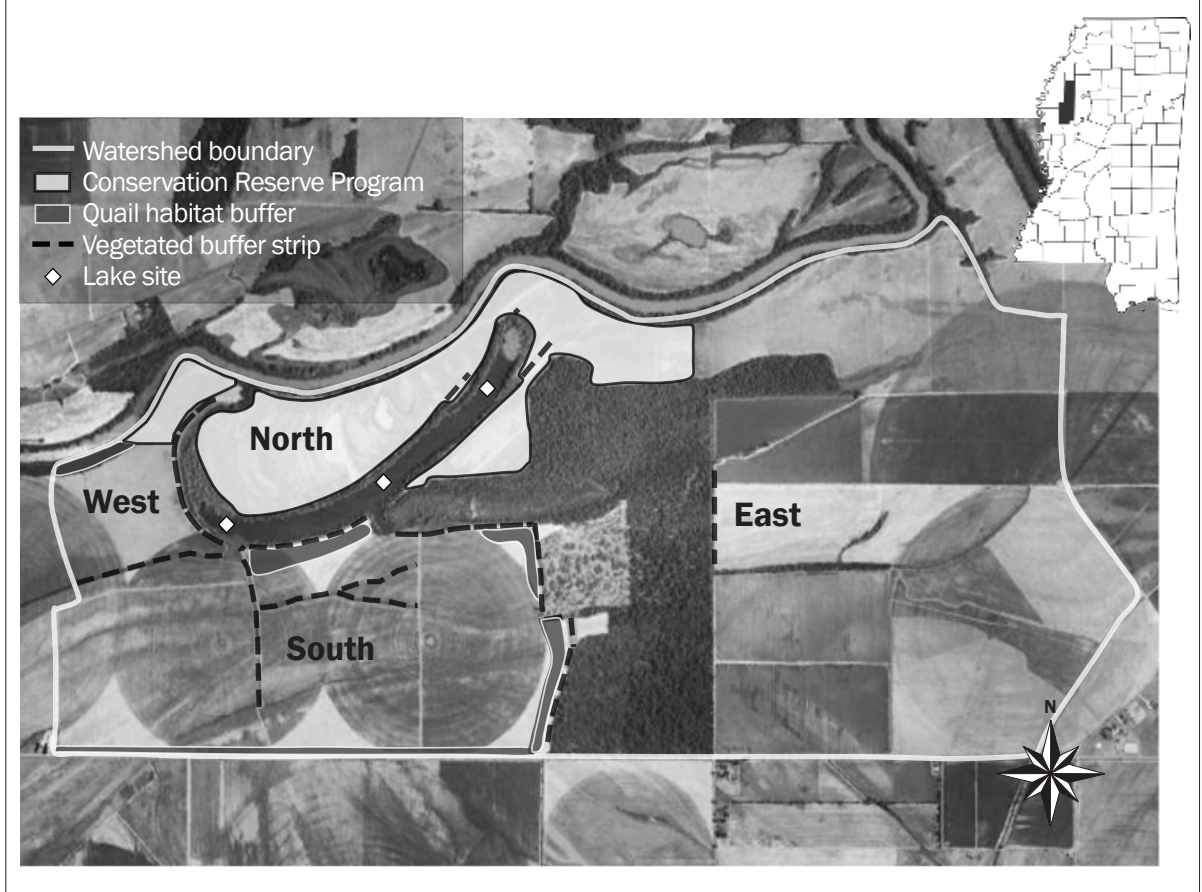

Table 1

Area of crops planted and conservation tillage in the Beasley Lake Watershed from 1996 to 2009.

\begin{tabular}{lllrrrrl}
\hline & \multicolumn{2}{l}{ Crop area (ha) } & & & & & \\
\cline { 2 - 7 } Year & Cotton & Soybeans & Corn & Milo & Rice & Wheat & $\begin{array}{l}\text { Conservation } \\
\text { tillage }\end{array}$ \\
\hline 1996 & 582 & 108 & 28 & 0 & 0 & 0 & 242.9 \\
1997 & 523 & 163 & 32 & 0 & 0 & 0 & 131.6 \\
1998 & 269 & 129 & 272 & 0 & 41 & 0 & 205.7 \\
1999 & 497 & 114 & 34 & 67 & 0 & 0 & 135.7 \\
2000 & 514 & 155 & 34 & 0 & 0 & 0 & 150.5 \\
2001 & 584 & 37 & 0 & 94 & 0 & 0 & 436.7 \\
2002 & 106 & 407 & 0 & 101 & 0 & 98 & 390.9 \\
2003 & 144 & 398 & 0 & 49 & 0 & 0 & - \\
2004 & 119 & 432 & 0 & 0 & 0 & 0 & 365.6 \\
2005 & 81 & 243 & 4 & 281 & 0 & 0 & 415.7 \\
2006 & 52 & 557 & 0 & 0 & 0 & 0 & 326.9 \\
2007 & 0 & 22 & 228 & 359 & 0 & 0 & 35.0 \\
2008 & 0 & 609 & 0 & 0 & 0 & 0 & 326.9 \\
2009 & 0 & 376 & 70 & 0 & 0 & 0 & 326.9
\end{tabular}

112 ha $(276 \mathrm{ac})$ of arable land north of the lake were removed from row crop production and planted in eastern cottonwood trees (Populus deltoides [Bartr. Ex. Marsh.]), oak trees (Quercus sp.), and hickory trees (Carya sp.) under implementation of Conservation Reserve Program (CRP) (Locke et al. 2008;
Cullum et al. 2010) (figure 1). Approximately 0.9 ha $(2.3 \mathrm{ac})$ of vegetative filter strips were subsumed into the Conservation Reserve Program (CRP). In the fall of 2006, 14.5 ha $(35.8 \mathrm{ac})$ of additional arable land along the southern lake shoreline were removed from row crop production and converted to 
vegetative buffer habitat to attract northern bobwhite quail (Colinus virginianus) (figure 1).

Water Quality Data Collection. Three lake sites were designated for water quality monitoring at the following locations: one-third distance from lake inflow, at lake midpoint, and one-third distance from lake outflow (figure 1). Water clarity was measured in situ at each lake monitoring site as depth of Secchi-disc visibility according to methods described by Scheffer (2004). At each monitoring location, approximately 1 L ( $0.264 \mathrm{gal})$ of water was collected at middistance from shoreline and within $5 \mathrm{~cm}$ (1.96 in) of the lake surface biweekly from January of 1996 through December of 2009 (Cullum et al. 2010). Immediately after collection, water samples were chilled on wet ice $\left(4^{\circ} \mathrm{C}\left[39.2^{\circ} \mathrm{F}\right]\right)$ and transported back to the USDA Agricultural Research Service (ARS) National Sedimentation Laboratory, Oxford, Mississippi, for analyses. Measured laboratory water quality parameters targeted for this study included total suspended solids (TSS, dried at $180^{\circ} \mathrm{C}\left[356^{\circ} \mathrm{F}\right]$ ) and total dissolved solids (TDS, filtered through a 45 $\mu \mathrm{m}[0.045 \mathrm{~mm}]$ cellulose nitrate $\left(\mathrm{NO}_{3}\right)$ filter and dried at $180^{\circ} \mathrm{C}\left[356^{\circ} \mathrm{F}\right]$ ), which were analyzed according to methods described by Eaton et al. (2005).

Water Quality Data Analysis. Due to the well-documented effects of seasonality on shallow lake water quality (Scheffer 2004), data were sorted by season a priori. Seasons were defined as follows: winter, December 21 to March 20; spring, March 21 to June 20; summer, June 21 to September 20; and fall, September 21 to December 20. Data analysis was conducted for each season independently using a one-way analysis of variance (ANOVA) or ANOVA on ranks (Kruskal-Wallis test), when appropriate, to test for changes over time of annual median values for Secchi depth, TSS, and TDS within winter, spring, summer, and fall. To facilitate assessment of combined changes in a water quality response through time after BMP implementation, a Dunn's multiple comparison test of post-BMP water quality median values versus 1996 reference (pre-BMP) median values were conducted. In order to further elucidate integrated effects of implementation of multiple BMPs over time and clearly link water quality changes, a series of linear or multiple linear regression analyses were completed to examine associations between changes in annual averages within winter, spring, summer, and fall of each tar- geted water quality parameter (dependent variable) and implementation of four major BMP types (independent variables) over the 14-year monitoring period (Tuppad et al. 2010). Because annual variations in seasonal rainfall is a potential confounding variable (figure 2), total seasonal rainfall for each year was also assessed as a potential independent variable within all linear and multiple linear regression analyses. Statistical significance level for all analyses was set at $\alpha \leq 0.05$ (Steel et al. 1997).

\section{Results and Discussion}

Water Clarity. Despite the land-use changes (crop rotations) and implementation of several BMPs, winter median Secchi depth (water clarity) in Beasley Lake only ranged from about 4 to $41 \mathrm{~cm}$ (1.5 to $16.1 \mathrm{in}$ ) during 1996 to 2009 (figure 3) with values typically $<15 \mathrm{~cm}(<5.9$ in) except in $1998(22 \mathrm{~cm}$ [8.6 in]), 2003 (17 cm [6.6 in]), and 2008 (41 cm [16.1 in]), indicating poor water clarity. Spring median Secchi depth ranged from about 5 to $38 \mathrm{~cm}$ (1.9 to 14.9 in) with values consistently increasing after implementation of three of the four BMPs (figure 3). Greatest water clarity occurred in summer and fall with median Secchi depths ranging from 7.5 to $69.5 \mathrm{~cm}$ (2.9 to 27.3 in) with values typically $>30 \mathrm{~cm}$ (11.8 in), indicating a greater than two-fold increase in water clarity versus winter. Changes in winter median Secchi depths as a percent of pre-BMP conditions varied between increasing and decreasing values relative to 1996 pre-BMP conditions (table 2). Water clarity was not consistently affected by vegetated buffer strips in place by 1996, but a significant increase in median Secchi depth of $144 \%$ was observed in winter of 1998 (table 2). In contrast, median Secchi depth significantly increased $44 \%$ to $120 \%$ after implementation of conservation tillage in 2001 for winter and spring (table 2). After implementation of CRP in 2003, median Secchi depth significantly increased by $28 \%$ to $360 \%$ each season (table 2). With the implementation of quail habitat buffers in 2005, Secchi depth consistently significantly increased by $44 \%$ to $600 \%$ each season (table 2). Secchi depth as a measure of water clarity has been an important tool in assessing the trophic status of lakes, and has been used as a measure of impairment due to eutrophication (excessive nutrients) (Dodds 2002; Knowlton and Jones 2006). However, reduced water clarity as a result of excessive suspended sediment uncouples the relationship between Secchi depth and algal biomass (as chlorophyll a) (Jones and Hubbart 2011) and confounds the effectiveness of Secchi depth as a tool to assess the effects of excessive nutrients on lake trophic status. In addition, decreases in water clarity, resulting from suspended sediment, indirectly adversely affects primary productivity in sestonic algae, benthic algae, and aquatic macrophytes by substantially limiting light availability throughout the water column (Torremorell et al. 2007; Devlin et al. 2008). Although suspended sediment reduces water clarity, this can occur naturally in shallow lakes as a result of resuspension of benthic sediment due to wind and wave action (Roozen et al. 2003; Kröger et al. 2011). However, in the current study, such climatic conditions are not the primary cause but rather agricultural practices, more specifically, tillage practices. A previous study by Cullum et al. (2010) focusing on assessing CRP in Beasley Lake Watershed noted a qualitative inverse relationship between TSS and Secchi depth with improvements in lake water clarity resulting from decreases in TSS as a result of edge-offield BMPs, increased use of transgenic crops, and implementation of CRP.

Total Suspended Solids. Several of the implemented BMPs were chosen specifically to target reductions in soil erosion and concomitant sediment runoff (Cullum et al. 2006; Locke 2004; Locke et al. 2008; Cullum et al. 2010). As a result, it was predicted that Beasley Lake TSS concentrations would decrease after implementation. The current study showed median TSS concentrations ranged from 4 to $869.5 \mathrm{mg} \mathrm{L}^{-1}(0.0005$ to $0.1161 \mathrm{oz} \mathrm{gal}^{-1}$ ) during 1996 to 2009 with distinct seasonal differences (figure 4). Again, although multiple watershed-wide BMPs were implemented, median winter lake TSS concentrations consistently exceeded $80 \mathrm{mg}$ $\mathrm{L}^{-1}\left(0.0107 \mathrm{oz} \mathrm{gal}{ }^{-1}\right)$ and ranged from 28.5 $\mathrm{mg} \mathrm{L}^{-1}\left(0.0038 \mathrm{oz} \mathrm{gal}^{-1}\right)$ in 2008 to $396.5 \mathrm{mg}$ $\mathrm{L}^{-1}\left(0.0529 \mathrm{oz} \mathrm{gal}^{-1}\right)$ in 1997. This was a result of farming practices during the study period where some postharvest fields (32\% to $94 \%$ of arable acreage) are cleared and late fall disking (conventional tillage) was done (late November to December) with additional disking in late winter (February) for preplanting field preparation in spring. Spring median lake TSS concentrations ranged from $34 \mathrm{mg} \mathrm{L}^{-1}\left(0.0045 \mathrm{oz} \mathrm{gal}^{-1}\right)$ in 2008 to 869.5 $\mathrm{mg} \mathrm{L}^{-1}\left(0.1161 \mathrm{oz} \mathrm{gal}^{-1}\right)$ in 1996 with values 


\section{Figure 2}

Total seasonal precipitation (mm) in Beasley Lake Watershed for four seasons ([a] winter, [b] spring, [c] summer, and [d] fall) from 1997 to 2009.

(a)

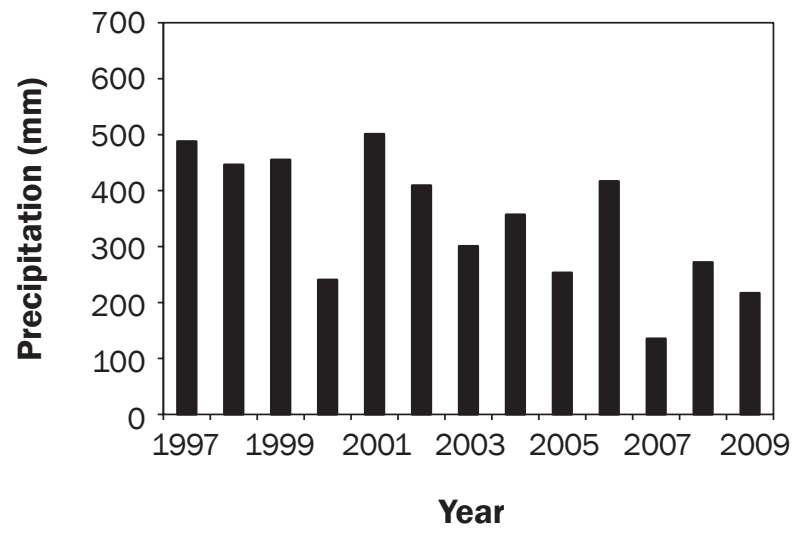

(c)

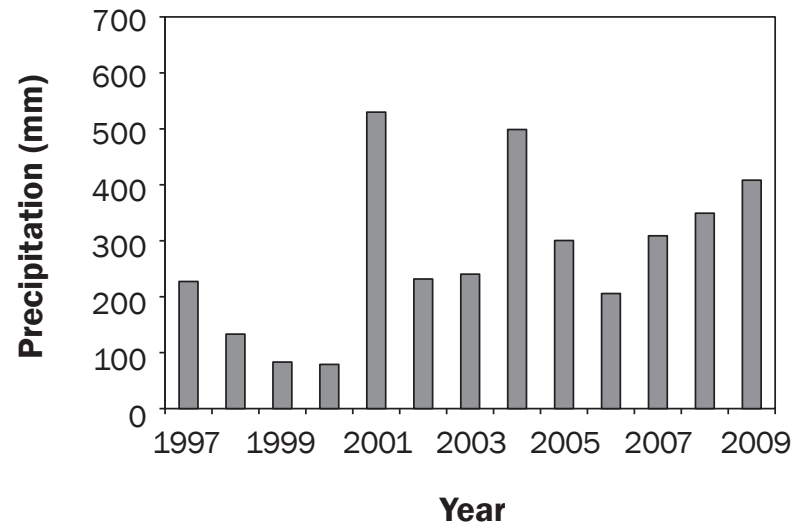

(b)

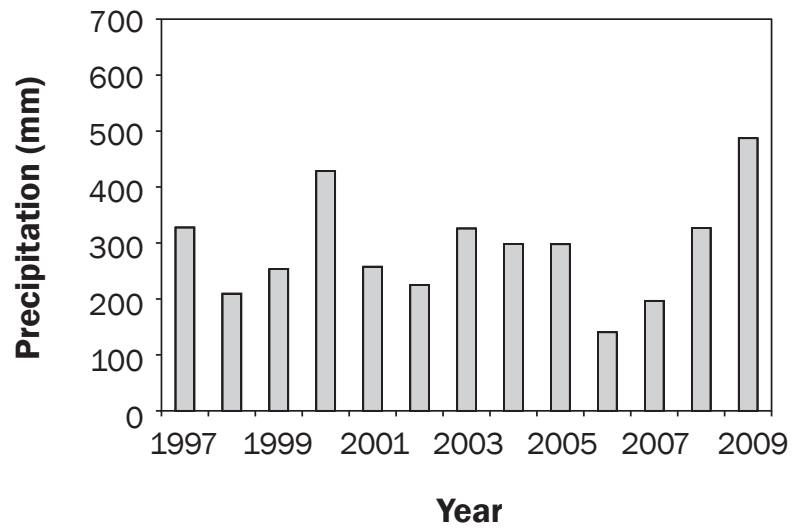

(d)

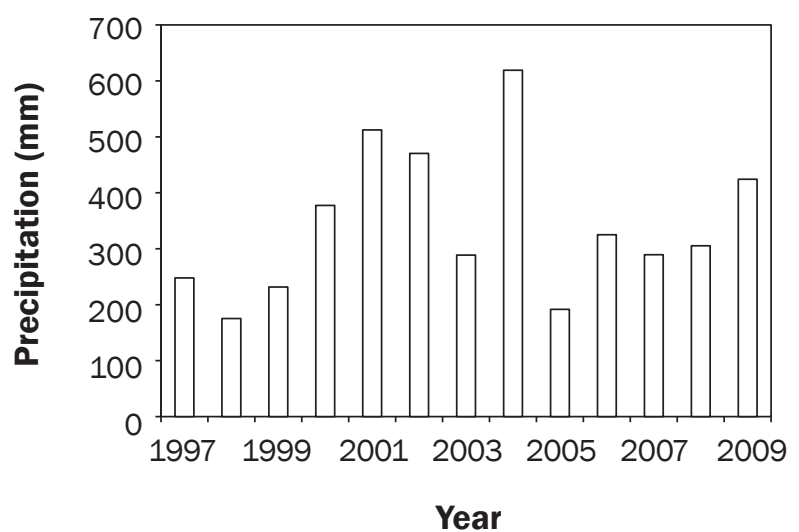

Table 2

Change in annual median values (\%) of measured Secchi depth (Secchi) within each season in Beasley Lake significantly $(p<0.05)$ decreased $(-)$ or increased $(+)$ versus reference (pre-BMP) year due to implementation of BMPs.

\begin{tabular}{|c|c|c|c|c|}
\hline \multirow{2}{*}{$\begin{array}{l}\text { BMP and } \\
\text { reference year } 1996\end{array}$} & \multicolumn{4}{|c|}{ Secchi $x$ season } \\
\hline & Winter & Spring & Summer & Fall \\
\hline \multicolumn{5}{|l|}{ Vegetated buffer strip } \\
\hline 1997 & -56 & +20 & -42 & +10 \\
\hline 1998 & $+144 *$ & 0 & $-64 *$ & -27 \\
\hline 1999 & -33 & +20 & $-79 *$ & $-67 *$ \\
\hline 2000 & +11 & 0 & -36 & -35 \\
\hline \multicolumn{5}{|l|}{ Conservation tillage } \\
\hline 2001 & -28 & $+120 *$ & +11 & +55 \\
\hline 2002 & $+44^{*}$ & $+120 *$ & -8 & +35 \\
\hline \multicolumn{5}{|c|}{ Conservation Reserve Program } \\
\hline 2003 & $+89 *$ & $+360 *$ & +31 & +67 \\
\hline 2004 & $+28 *$ & $+270 *$ & +44 & +59 \\
\hline 2005 & 0 & $+180 *$ & $+75^{*}$ & $+137 *$ \\
\hline \multicolumn{5}{|l|}{ Quail habitat buffer } \\
\hline 2006 & $+56 *$ & $+540 *$ & +39 & $+96 *$ \\
\hline 2007 & $+50 *$ & $+600 *$ & $+89 *$ & $+151 *$ \\
\hline 2008 & $+356 *$ & $+660 *$ & $+67 *$ & $+184 *$ \\
\hline 2009 & $+44 *$ & $+455 *$ & +53 & $+141 *$ \\
\hline
\end{tabular}

consistently $>100 \mathrm{mg} \mathrm{L}^{-1}\left(>0.0134 \mathrm{oz} \mathrm{gal}^{-1}\right)$ from 1996 to 2002 and $<80 \mathrm{mg} \mathrm{L}^{-1}(<0.0107$ $\mathrm{oz} \mathrm{gal}^{-1}$ ) from 2003 to 2009 in conjunction with BMPs (figure 4). Lowest lake TSS concentrations occurred in summer and fall with median TSS concentrations ranging from 4 to $149 \mathrm{mg} \mathrm{L}^{-1}$ (0.0005 to $0.0199 \mathrm{oz} \mathrm{gal}^{-1}$ ) with median concentrations frequently $<40$ $\mathrm{mg} \mathrm{L}^{-1}\left(<0.0053 \mathrm{oz} \mathrm{gal}^{-1}\right)$ (figure 4) indicating suspended sediment settling out of the lake water column (Knowlton and Jones 1995). Effects of TSS on aquatic biota have been well documented, and recent reviews by Henley et al. (2000) and Bilotta and Brazier (2008) provide extensive literature on the ecological impacts of TSS. Primary productivity by sestonic algae can be reduced by $13 \%$ to $50 \%$ at TSS concentrations as low as $40 \mathrm{mg} \mathrm{L}^{-1}\left(0.0053 \mathrm{oz} \mathrm{gal}^{-1}\right)$, and benthic algae and aquatic macrophytes can be affected by TSS $>100 \mathrm{mg} \mathrm{L}^{-1}(>0.0134 \mathrm{oz}$ $\mathrm{gal}^{-1}$ ) after as little as one week of exposure (Cooper 1993; Bilotta and Brazier 2008). These effects can be direct (smothering, abrasion, etc.) or indirect as a result of light limitation as previously described. Aquatic 
Figure 3

Box-whisker plots of Secchi depth (water clarity) and year of best management practice implementation (vegetative buffer strip [VBS], conservation tillage [CT], Conservation Reserve Program [CRP], and quail buffer [QB]) in Beasley Lake Watershed for four seasons ([a] winter, [b] spring, [c] summer, and [d] fall) from 1996 to 2009.

(a)

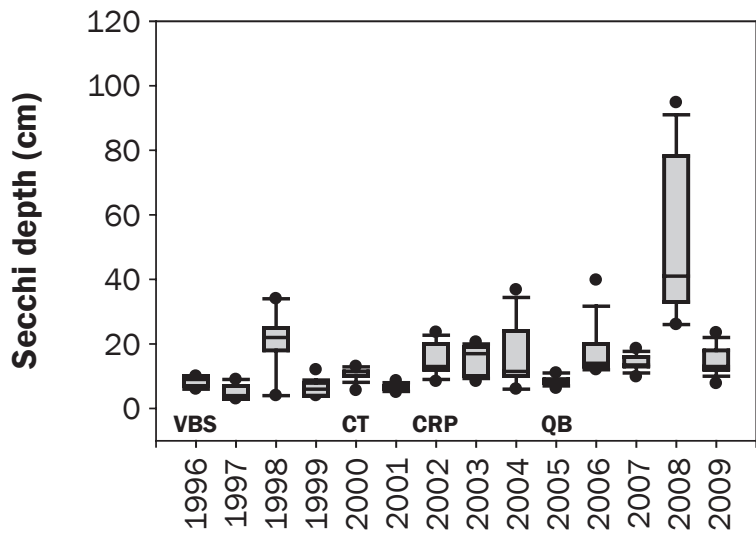

Year

(c)

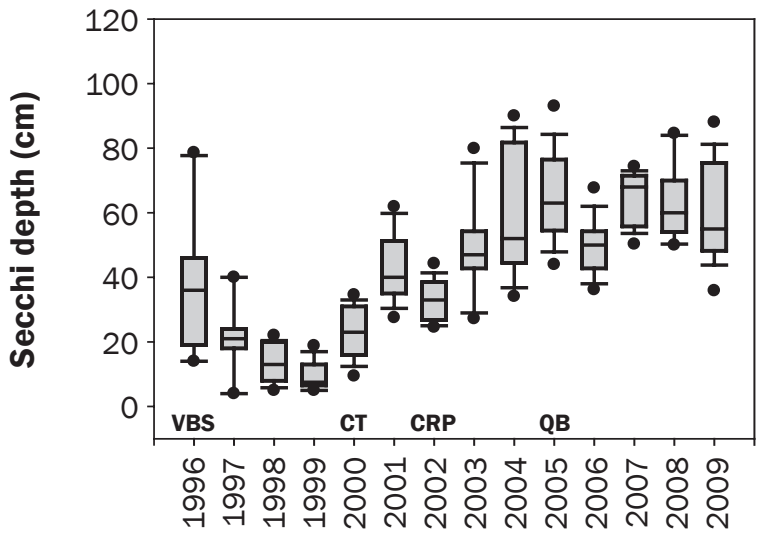

Year (b)

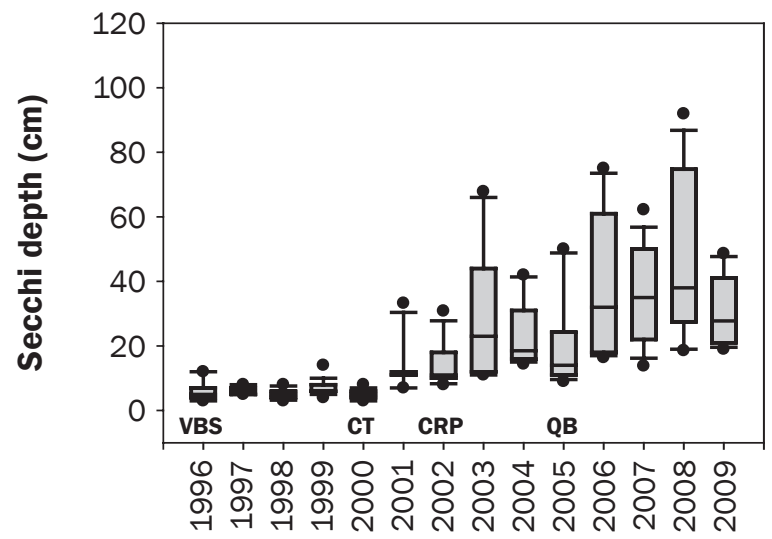

Year

(d)

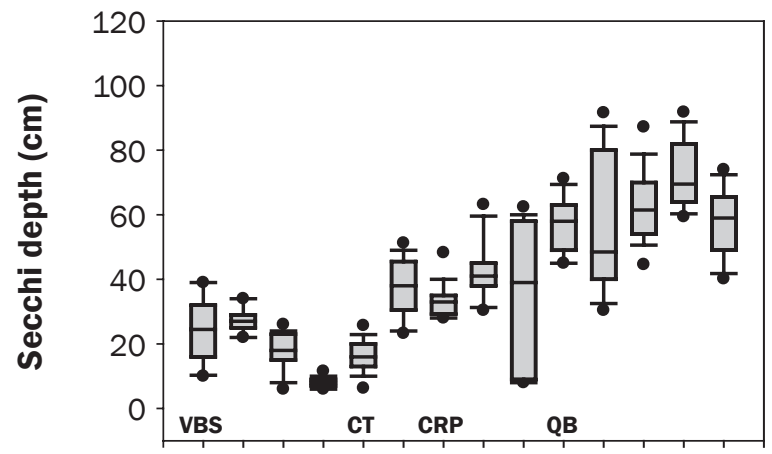

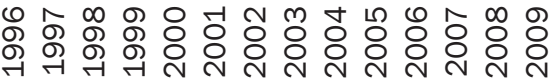

Year

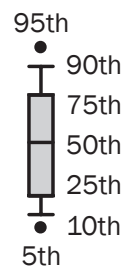

invertebrates and fish population abundance and community diversity can be reduced at concentrations $>80 \mathrm{mg} \mathrm{TSS} \mathrm{L}^{-1}(>0.0107 \mathrm{oz}$ $\mathrm{gal}^{-1}$ ) after only one to four weeks of exposure (Bilotta and Brazier 2008). Excessive TSS impacts aquatic biota beginning with the primary trophic level and producing a negative cascade through the aquatic food web by reducing food availability to primary and secondary consumers (e.g., aquatic invertebrates and fish) (Henley et al. 2000).

Changes in winter median TSS as a per- centage of 1996 pre-BMP conditions varied between increasing and decreasing values relative to pre-BMP conditions (table 3). Spring median lake TSS concentrations were significantly reduced by $67 \%$ to $69 \%$ by vegetated buffer strips in place by 1996, but changes in TSS during other seasons were inconsistent (table 3). After implementation of conservation tillage in 2001, median lake TSS concentrations significantly decreased by $77 \%$ to $87 \%$ for every season except summer (table 3). After implementation of CRP in 2003, median lake TSS concentrations significantly decreased by $68 \%$ to $95 \%$ during winter, spring, and fall only, with no observed significant changes in TSS during summer (table 3). With the implementation of quail habitat buffers in 2005, lake TSS consistently significantly decreased by $57 \%$ to $92 \%$ in winter 2006 to $2009,92 \%$ to $96 \%$ in spring 2006 to 2009 , and $85 \%$ to $95 \%$ in fall but not summer (table 3), indicating a possible upper limit of decreasing TSS loads in the lake for spring and fall seasons. Observed patterns 


\section{Figure 4}

Box-whisker plots of total suspended solids concentrations and year of best management practice implementation (vegetative buffer strip [VBS], conservation tillage [CT], Conservation Reserve Program [CRP], and quail buffer [QB]) in Beasley Lake Watershed for four seasons ([a] winter, [b] spring, [c] summer, and [d] fall) from 1996 to 2009.
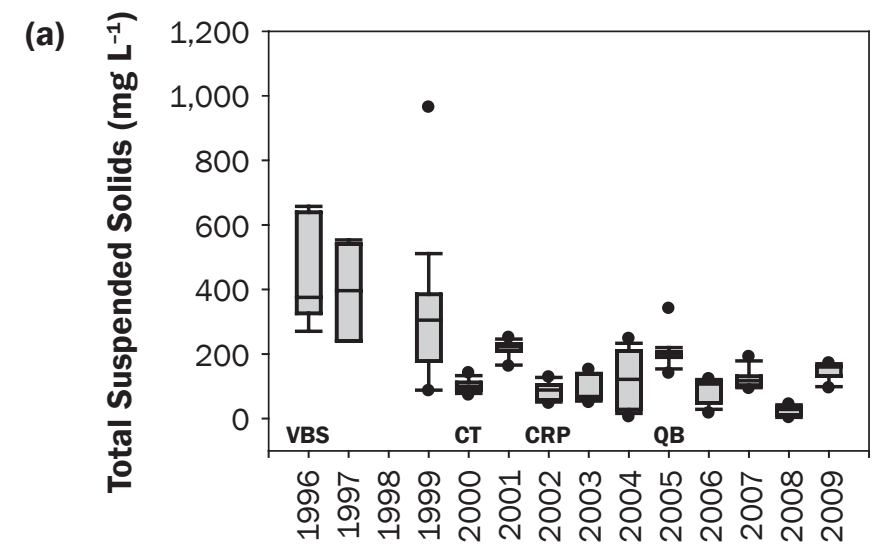

Year

(c)

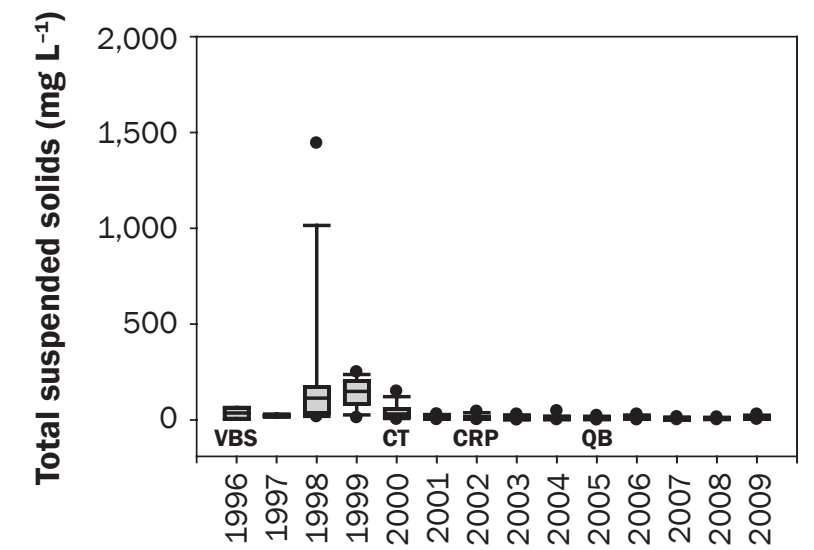

Year (b)

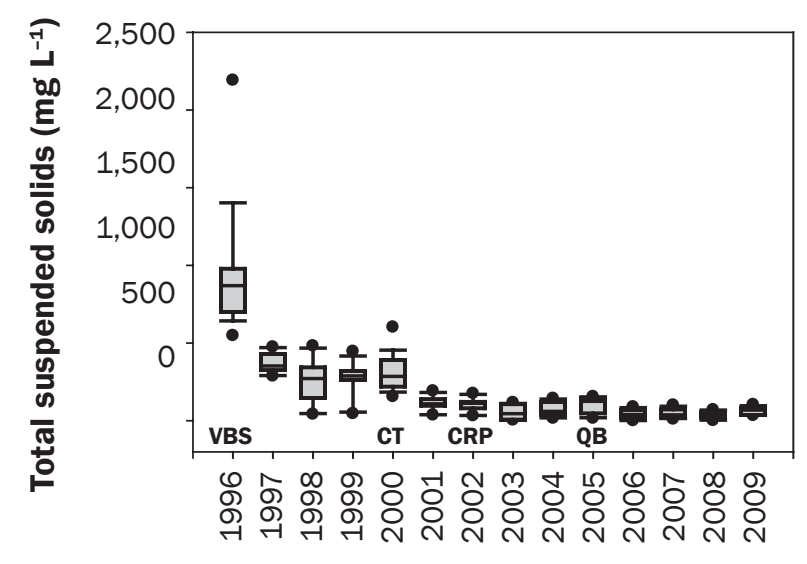

Year

(d)

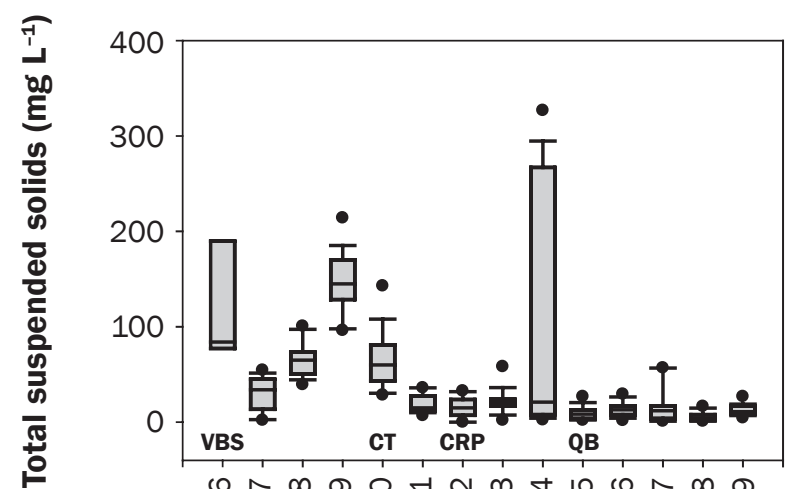

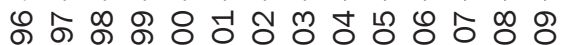

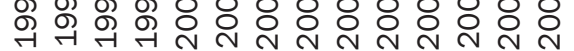

Year of TSS changes were inversely proportional to changes in Secchi depth showing lake water clarity was directly dependent upon inputs of suspended sediments (figure 5). Lake TSS concentrations explained $>74 \%$ of the observed variation in winter water clarity, $>72 \%$ of the variation in water clarity observed in spring, but only about $60 \%$ to $70 \%$ of the variation in summer and fall (figure 5) indicating suspended sediment had a lesser impact on water clarity during the latter two seasons. Observed changes in
TSS in the current study are supported by a landscape-scale study by Dodds and Whiles (2004) showing increased TSS concentrations were associated with agriculture (both rangeland and cropland) and decreased TSS concentrations coincided with increased forest cover. In the present study, when arable land is converted to vegetated buffer strips and quail buffer habitat, spring TSS loads into the lake consistently decrease.

Total Dissolved Solids. Lake TDS is indicative of dissolved salts (including minerals) and organic residue present in the water column (Cole 1983; Dodds 2002). These constituents enter lake systems through weathering and erosion from upland sources and irrigation water and are transported in runoff to the lake (Dodds 2002; Zeng and Rasmussen 2005; Anning 2011; Nagy et al. 2011). Beasley Lake median TDS concentrations from 1996 to 2009 ranged from 44 to $91 \mathrm{mg} \mathrm{L}^{-1}$ (0.0059 to $\left.0.0122 \mathrm{oz} \mathrm{gal}^{-1}\right)$ with no distinct seasonal patterns evident (figure 6). Winter median lake TDS concentrations 


\section{Table 3}

Change in annual median values (\%) of measured total suspended solids (TSS) within each season in Beasley Lake significantly $(p<0.05)$ decreased $(-)$ or increased $(+)$ versus reference (pre-BMP) year due to implementation of BMPs.

\begin{tabular}{|c|c|c|c|c|}
\hline \multirow{2}{*}{$\begin{array}{l}\text { BMP and } \\
\text { reference year } 1996\end{array}$} & \multicolumn{4}{|c|}{ TSS x season } \\
\hline & Winter & Spring & Summer & Fall \\
\hline \multicolumn{5}{|l|}{ Vegetated buffer strip } \\
\hline 1997 & +6 & -59 & -42 & -60 \\
\hline 1998 & - & $-69 *$ & +215 & -23 \\
\hline 1999 & -19 & $-67 *$ & +314 & +73 \\
\hline 2000 & $-74 *$ & -67 & -14 & -29 \\
\hline \multicolumn{5}{|l|}{ Conservation tillage } \\
\hline 2001 & -41 & $-87 *$ & -61 & -82 \\
\hline 2002 & $-77 *$ & $-87 *$ & -69 & $-82 *$ \\
\hline \multicolumn{5}{|c|}{ Conservation Reserve Program } \\
\hline 2003 & $-82 *$ & $-95 *$ & -58 & -76 \\
\hline 2004 & $-68 *$ & $-93 *$ & -81 & -75 \\
\hline 2005 & -46 & $-86 *$ & -36 & $-90 *$ \\
\hline \multicolumn{5}{|l|}{ Quail habitat buffer } \\
\hline 2006 & $-72 *$ & $-95 *$ & -64 & $-85 *$ \\
\hline 2007 & $-69 *$ & $-96 *$ & -89 & $-86 *$ \\
\hline 2008 & $-92 *$ & $-96 *$ & -83 & $-95 *$ \\
\hline 2009 & $-57 *$ & $-92 *$ & -64 & $-87 *$ \\
\hline
\end{tabular}

ranged from 44.5 to $73 \mathrm{mg} \mathrm{L}^{-1}(0.0059$ to $0.0097 \mathrm{oz} \mathrm{gal}^{-1}$ ) during 1996 to 2009 with concentrations frequently 50 to $60 \mathrm{mg} \mathrm{L}^{-1}$ ( 0.0067 to $0.0080 \mathrm{oz} \mathrm{gal}^{-1}$ ) except in 1996 , 1999, and 2000 indicating limited variation in annual median winter TDS (figure 6). Similar TDS patterns were observed for spring through summer with Beasley Lake TDS concentrations commonly 55 to 65 $\mathrm{mg} \mathrm{L}^{-1}$ (0.0073 to $0.0087 \mathrm{oz} \mathrm{gal}^{-1}$ ) (figure 6). Although not typically considered to be a major pollutant, a study by Meador and Goldstein (2003) noted decreased fish community condition was associated with TDS $>400 \mathrm{mg} \mathrm{L}^{-1}\left(>0.0534 \mathrm{oz} \mathrm{gal}^{-1}\right)$ in locations where agricultural land use was $>50 \%$, implying that excessive agriculturally derived TDS can have adverse effects on aquatic biota. In the present study, TDS concentrations never exceeded $200 \mathrm{mg} \mathrm{L}^{-1}$ (0.0267 $\left.\mathrm{Oz} \mathrm{gal}^{-1}\right)$, and as a result, TDS concentrations in Beasley Lake are unlikely to be a source of ecological impairment. Changes in winter and spring median TDS as a percent of 1996 pre-BMP conditions varied between increasing and decreasing concentrations relative to pre-BMP conditions with a significant increases of $64 \%$ in the winter of 2000 after implementation of vegetated buffer strips and a decrease of $28 \%$ occurring only after implementation of CRP in 2003 (table 4). Summer median lake TDS concen- trations were significantly reduced by $31 \%$ to $39 \%$ after implementation of conservation tillage in $2001,35 \%$ to $40 \%$ after implementation of CRP, and $35 \%$ to $44 \%$ after establishment of quail buffer habitat (table 4). Fall median TDS concentrations were significantly reduced by $38 \%$ to $40 \%$ after implementation of vegetated buffer strips in 1996 and again significantly reduced by $43 \%$ to $45 \%$ after implementation of CRP in 2003. Implementation of quail buffer habitat in 2006 resulted in significant reductions of TDS concentrations by $35 \%$ to $50 \%$ in summer and fall (table 4). An earlier study in the same watershed by Cullum et al. (2006) observed a moderate increase (12\%) in TDS in Beasley Lake from 1996 to 1999 after implementation of edge-of-field BMPs; however no attempt was made to address seasonal differences in TDS, which accounts for the limited agreement with the current study.

Regression Models. Over the course of the 14-year monitoring period, the watershed has had significant shifts in cropping patterns from (1) primarily conventional tillage cotton to predominantly conservation tillage soybean, to (2) mixtures of corn-soybean and milo-soybean. These shifts in cropping patterns were in addition to implementation of four major independent conservation BMPs described previously. Multiple water quality parameters of water clarity, suspended sediment, and dissolved solids responded most dramatically to combinations of two BMPs: implementation of VBS throughout the watershed and CRP north of the lake. Assessment of the integrated combined effects of these BMPs on lake water quality using linear and multiple linear regression models showed all three water quality variables were influenced by implementation of integrated multiple BMPs over time (table 5). Models of average winter Secchi depth showed quail buffer had the greatest explanatory power, accounting for $31 \%$ of winter water clarity $\left(r^{2}=0.316\right)$. The best spring and fall models of Secchi depth showed CRP provided the best model and explained $80 \%$ and $69 \%$ of the variation in water clarity, respectively (table 5). The best summer model of Secchi depth indicated that a combination of climate (summer rainfall) and BMP type (CRP) accounted for $91 \%$ of the variation in water clarity from 1996 to 2009.

Regression analysis of average winter TSS concentrations showed implementation of VBS throughout the watershed explained $53 \%$ of the winter TSS variation during the study period. The best spring regression model of TSS showed CRP north of the lake accounted for $67 \%$ of spring TSS variation. The best summer TSS regression model again showed a combination of summer rainfall and CRP explained $69 \%$ of summer TSS variation. The strongest fall TSS regression model showed VBS explained only $38 \%$ of fall TSS variation (table 5). Regression analysis of average winter TDS concentrations provided no statistically significant model with any single or combination of the BMPs assessed in this study. Regression models with the greatest explanatory power of average spring and summer TDS showed VBS throughout the watershed accounted for $54 \%$ and $64 \%$ of the variation in lake TDS concentrations, respectively. Fall TDS data provided only a single statistically significant regression model showing CRP explained $42 \%$ of fall TDS variation (table 5 ).

Watershed-scale longer-term ( $>10$ years) studies such as the current study are essential to improved understanding of how agriculturally impacted lakes can be rehabilitated and sustained using multiple integrated conservation BMPs. Several studies are available quantifying mitigation of agricultural runoff using a specific type of BMP, such as vegetative filter strips (Liu et al. 2008), reduced tillage practices (Schreiber et al. 2001), and 


\section{Figure 5}

Seasonal exponential linear regressions of total suspended solids concentrations vs. Secchi depth in Beasley Lake Watershed for four seasons ([a] winter, [b] spring, [c] summer, and [d] fall) from 1996 to 2009.

(a)

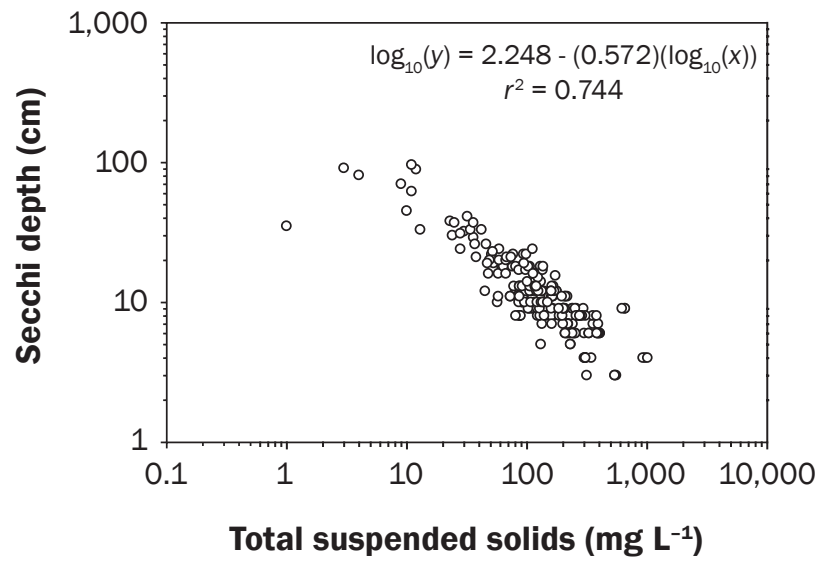

(c)

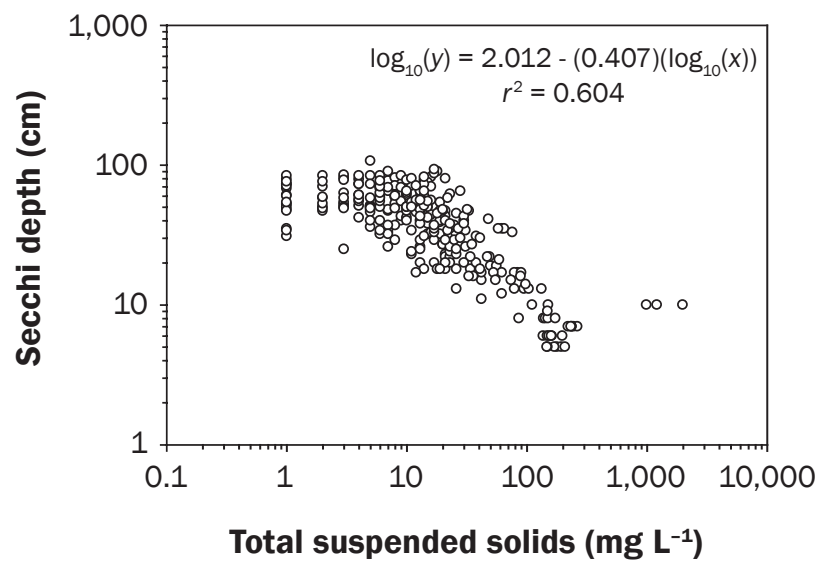

(b)

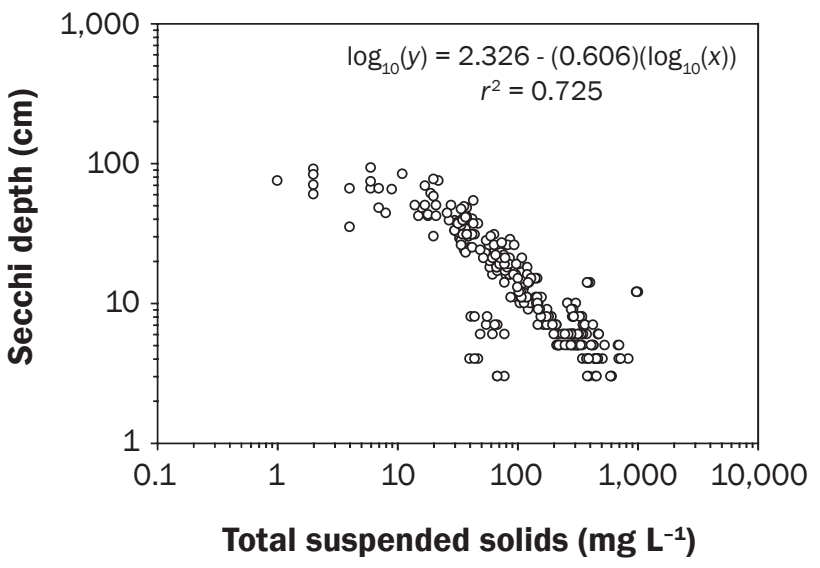

(d)

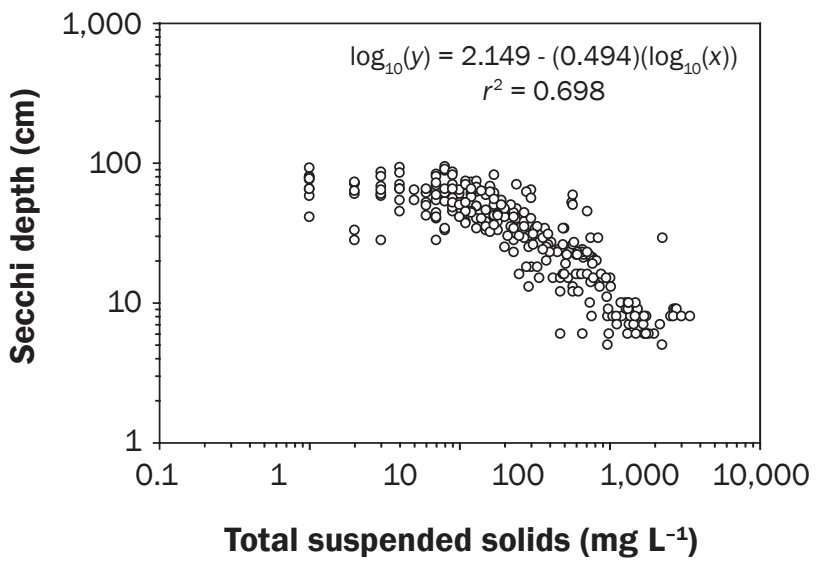

conservation reserve practices (Cullum et al. 2010) at smaller, field scales. Other studies have tried to assess the effects of combined BMPs on sediment reduction, but again only at the field scale (Zeimen et al. 2006). Fewer studies have attempted to assess these BMPs at a watershed scale (Cullum et al. 2006; Locke et al. 2008; Zablotowicz et al. 2006; Yuan et al.2008; Makarewicz et al.2009). The current study observed continuing improved lake surface water conditions with combined implementation of a variety of BMPs from structural localized edge-of-field practices in 1996 and 2006, to watershed-wide cultural practices such as reduced tillage in 2001 and watershed-wide structural practices such as the CRP in 2003. The underlying goal of these BMPs has been to reduce pollutant loadings into the lake, beginning with suspended sediment. Suspended sediments derived from erosion of loose soil during runoff events on agricultural land is the pri- mary source of ecological degradation in oxbow lakes in southeastern United States (Cooper 1993). Suspended sediments, themselves, can have direct effects on the integrity of lake ecosystems by limiting water clarity, primary productivity, and decreasing animal diversity (Cooper 1993; Jones et al. 2008; Jones and Hubbart 2011). Sediments can also transport nutrients, such as soil-bound P (Schreiber et al. 2001; Yuan et al. 2008), causing eutrophic and hypertrophic conditions within the lake after sediments settle from the water column and reduced light attenuation is no longer limiting primary production. As a result, reductions in TSS concentrations within Beasley Lake surface water due to integrated implementation of multiple BMPs within the watershed likely induced a cascade of concomitant changes, such as decreased nutrients, increased primary productivity (algal biomass), and increased water clarity, leading to lake rehabilitation and sustainability.

\section{Summary and Conclusions}

Results of the current study provide a greater understanding of the role of agricultural BMPs in improving water quality and improved capability of predicting changes in lake water quality after watershed-wide changes in land use patterns. Watershed-wide implementation of multiple agricultural BMPs over the course of the 14-year study period reduced sediments while increasing water clarity, especially during spring and summer. Beasley Lake spring TSS decreased nearly every year after implementation of all four major BMPs examined. Beasley Lake water clarity increased after implementation of conservation tillage (2001 to 2002) followed by implementation of CRP (2003 to 2004) and quail habitat buffer (2006) BMPs and continued thereafter. These results are 


\section{Figure 6}

Box-whisker plots of total dissolved solids concentrations and year of best management practice (BMP) implementation (vegetative buffer strip [VBS], conservation tillage [CT], Conservation Reserve Program [CRP], and quail buffer [QB]) in Beasley Lake Watershed for four seasons ([a] winter, [b] spring, [c] summer, and [d] fall) from 1996 to 2009.

(a)

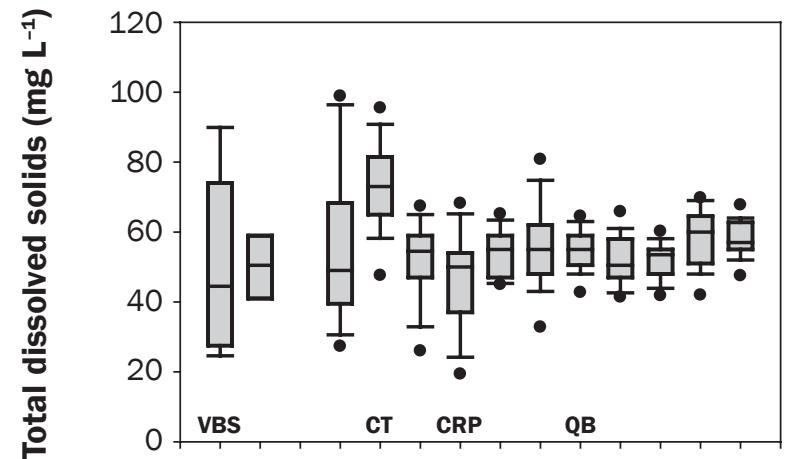

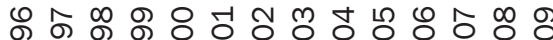

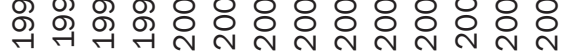

Year

(c)

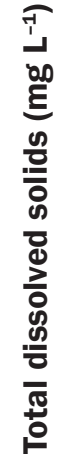

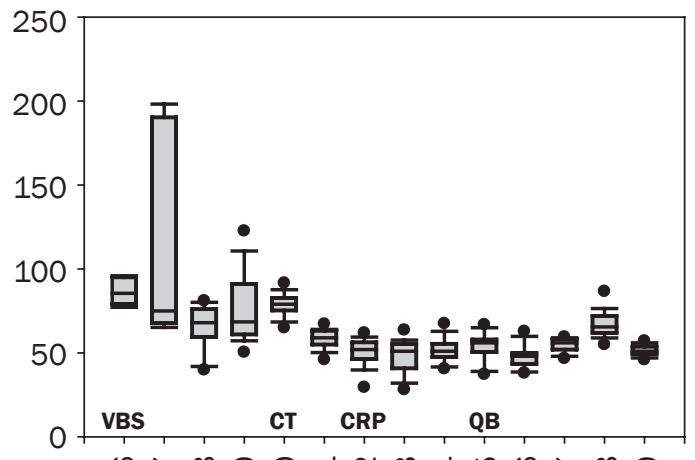

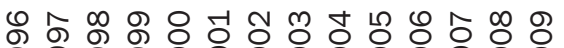

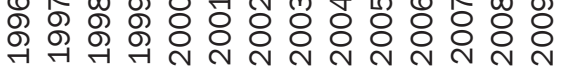

Year

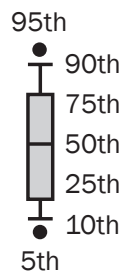

(b)

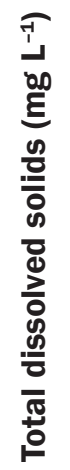

(d)

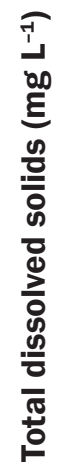

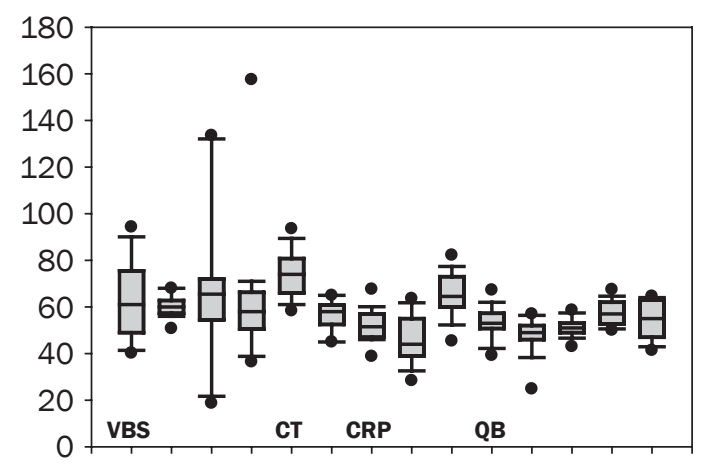

ํํ요

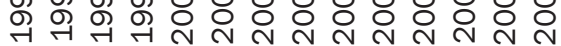

\section{Year}

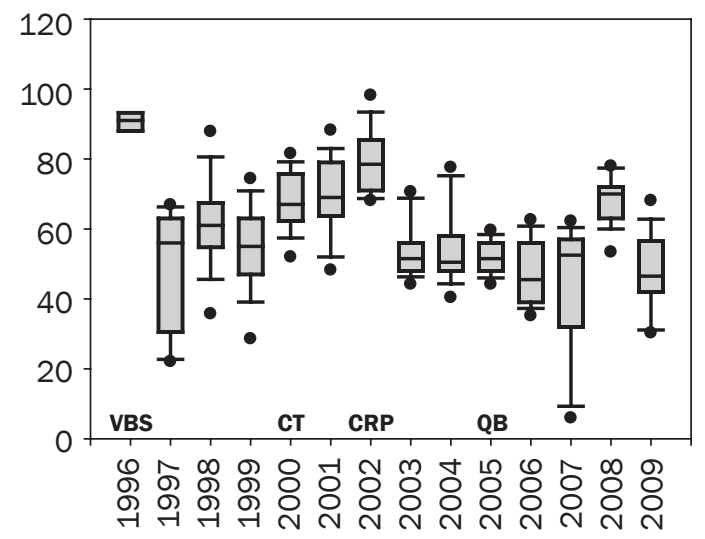

Year

valuable for assisting researchers and lake managers in attaining and maintaining a healthy, sustainable lake ecosystem.

\section{Acknowledegements}

The authors especially thank Charles Bryant a biologist with the USDA Agricultural Research Service (ARS) National Sedimentation Laboratory in Oxford, Mississippi, for sample collection; Wade Steinriede a biologist with the USDA ARS National Sedimentation Laboratory in Oxford, Mississippi, for collection and maintenance of land management information; and Sam Testa, also a biologist with the USDA ARS National Sedimentation Laboratory in Oxford, Mississippi.
We also want to thank Lisa Brooks a biological science technician with the USDA ARS National Sedimentation Laboratory in Oxford, Mississippi, and James Hill a chemist with the USDA ARS National Sedimentation Laboratory in Oxford, Mississippi, for their technical assistance. In addition, the authors thank the numerous scientists and technicians who contributed and assisted with this study over the 14-year monitoring period.

\section{References}

Anning, D.W. 2011. Modeled sources, transport, and accumulation of dissolved solids in water resources of the southwestern United States. Journal of the American Water Resources Association 47:1087-1109.

Bennett, H.H., and W.R. Chapline. 1928. Soil erosion a national menace. USDA Circ. 33. Washington, DC: US Government Print Office.

Bilotta, G.S., and R.E. Brazier. 2008. Understanding the influence of suspended solids on water quality and aquatic biota. Water Research 42:2849-2861.

Cole, G.A. 1983. Textbook of Limnology, 3rd ed. Prospect Heights, IL:Waveland Press, Inc.

Cooper, C.M. 1993. Effects of suspended sediment reduction on chlorophyll and water quality in a large natural lake. 
Table 4

Change in annual median values (\%) of measured total dissolved solids (TDS) within each season in Beasley Lake significantly $(p<0.05)$ decreased $(-)$ or increased $(+)$ versus reference (pre-BMP) year due to implementation of BMPs.

\begin{tabular}{|c|c|c|c|c|}
\hline \multirow{2}{*}{$\begin{array}{l}\text { BMP and } \\
\text { reference year } 1996\end{array}$} & \multicolumn{4}{|c|}{ TDS $x$ season } \\
\hline & Winter & Spring & Summer & Fall \\
\hline \multicolumn{5}{|l|}{ Vegetated buffer strip } \\
\hline 1997 & +13 & -2 & -12 & $-38 *$ \\
\hline 1998 & - & +7 & -20 & -33 \\
\hline 1999 & +10 & -5 & -20 & $-40 *$ \\
\hline 2000 & $+64 *$ & +21 & -8 & -26 \\
\hline \multicolumn{5}{|l|}{ Conservation tillage } \\
\hline 2001 & +22 & -5 & $-31 *$ & -24 \\
\hline 2002 & +12 & -16 & $-39 *$ & -14 \\
\hline \multicolumn{5}{|c|}{ Conservation Reserve Program } \\
\hline 2003 & +24 & $-28 *$ & $-40 *$ & $-43 *$ \\
\hline 2004 & +24 & +6 & $-40 *$ & $-45^{*}$ \\
\hline 2005 & +24 & -13 & $-35 *$ & $-43 *$ \\
\hline \multicolumn{5}{|l|}{ Quail habitat buffer } \\
\hline 2006 & +13 & $+20 *$ & $-44 *$ & $-50 *$ \\
\hline 2007 & +20 & -16 & $-35 *$ & $-42^{*}$ \\
\hline 2008 & +35 & -7 & -23 & -23 \\
\hline 2009 & +28 & -10 & $-40 *$ & $-49 *$ \\
\hline
\end{tabular}

Verhandlungen des Internationalen Verein Limnologie 25:392-395.

Cooper, C.M., and W.M. Lipe. 1992. Water quality and agriculture: Mississippi experiences. Journal of Soil and Water Conservation 47:220-223.

Cullum, R.F., S.S. Knight, C.M. Cooper, and S. Smith. 2006. Combined effects of best management practices on water quality in oxbow lakes from agricultural watersheds. Soil \& Tillage Research 90:212-221.

Cullum, R.F., M.A. Locke, and S.S. Knight. 2010. Effects of conservation reserve program on runoff and lake water quality in an oxbow lake watershed. Journal of International Environmental Application \& Science 5:318-328.
Devlin, M.J., J. Barry, D.K. Mills, R.J. Gowen, J. Foden, D. Sivyer, and P. Tett. 2008. Relationships between suspended particulate material, light attenuation and Secchi depth in UK marine waters. Estuarine, Coastal and Shelf Science 79:429-439.

Dodds, W.K. 2002. Freshwater Ecology: Concepts and Environmental Applications. San Diego, CA: Academic Press.

Dodds, W.K., and M.R. Whiles. 2004. Quality and quantity of suspended particles in rivers: Continent-scale patterns in the United States. Environmental Management 33:355-367.

Donahue, I., and J.G. Molinos. 2009. Impacts of increased sediment loads on the ecology of lakes. Biological Reviews 84(4):517-531.

Eaton, A.D., L.S. Clesceri, E.W. Rice, and A.E. Greenburg. 2005. Standard Methods for the Examination of Water and Wastewater, 21st ed. Washington, DC: American Public Health Association, American Water Works Association, and Water Environment Federation.

Henley, W.F., M.A. Patterson, R.J. Neves, and A.D. Lemly. 2000. Effects of sedimentation and turbidity on lotic food webs: A concise review for natural resource managers. Fisheries Science 8:125-139.

Jones, J.R., D.V. Obrecht, B.D. Perkins, M.F. Knowlton, A.P. Thorpe, S. Watanabe, and R.R. Bacon. 2008. Nutrients, seston, and transparency of Missouri reservoirs and oxbow lakes: An analysis of regional limnology. Lake and Reservoir Management 24:155-180.

Jones, J.R., and J.A. Hubbart. 2011. Empirical estimation of non-chlorophyll light attenuation in Missouri reservoirs using deviation from the maximum observed value in

\section{Table 5}

Equations and coefficients of determination $\left(r^{2}\right)$ for linear and multiple linear regressions computed using seasonal Beasley Lake average Secchi depth, average total suspended solids (TSS), and average total dissolved solids (TDS) as dependent variables ( $y$ ) and BMP type (vegetated buffer strip [VBS], conservation tillage [CT], Conservation Reserve Program [CRP], and quail habitat buffer [QB]), and total annual precipitation for each season (rain) as independent variables $(x)$ from 1996 to 2009.

\begin{tabular}{|c|c|c|c|c|c|c|c|}
\hline $\begin{array}{l}\text { Land-use } \\
\text { by season }\end{array}$ & (n) & $y$ & $x_{1}$ & $x_{2}$ & Equation & $r^{2}$ & $p$-value \\
\hline \multicolumn{8}{|l|}{ BMP type } \\
\hline Winter & 14 & Secchi & QB & & $y=11.799+\left(1.076 x_{1}\right)$ & 0.316 & 0.036 \\
\hline Winter & 13 & TSS & VBS & & $y=685.902-\left(69.679 x_{1}\right)$ & 0.530 & 0.005 \\
\hline Spring & 14 & Secchi & CRP & & $\log _{10} y=0.881+\left(0.0055 x_{1}\right)$ & 0.803 & $<0.001$ \\
\hline Spring & 14 & TSS & CRP & & $\log _{10} y=2.422-\left(0.00599 x_{1}\right)$ & 0.665 & $<0.001$ \\
\hline Spring & 14 & TDS & VBS & & $y=89.092-\left(4.346 x_{1}\right)$ & 0.541 & 0.003 \\
\hline Summer & 13 & Secchi & Rain* & CRP & $y=12.532+\left(0.0536 x_{1}\right)+\left(0.255 x_{2}\right)$ & 0.911 & $<0.001$ \\
\hline Summer & 13 & TSS & Rain* & VBS & $\log _{10} y=3.179-\left(0.00161 x_{1}\right)-\left(0.198 X_{2}\right)$ & 0.693 & 0.003 \\
\hline Summer & 14 & TDS & VBS & & $\log _{10} y=2.250-\left(0.0639 x_{1}\right)$ & 0.636 & $<0.001$ \\
\hline Fall & 14 & Secchi & CRP & & $y=23.479+\left(0.283 x_{1}\right)$ & 0.693 & $<0.001$ \\
\hline Fall & 14 & TSS & VBS & & $\log _{10} y=2.876-\left(0.199 x_{1}\right)$ & 0.376 & 0.020 \\
\hline Fall & 14 & TDS & CRP & & $\log _{10} y=1.831-\left(0.00104 x_{1}\right)$ & 0.415 & 0.013 \\
\hline
\end{tabular}

* Total annual summer rain 
the Secchi-Chlorophyll relationship. Lake and Reservoir Management 27(1):1-5.

Karlen, D.L. 2008. A new paradigm for natural resources research: The Conservation Effects Assessment Project. Journal of Soil and Water Conservation 63:220A doi:10.2489/jswc.63.6.220A.

Knowlton, M.F., and J.R. Jones. 1995. Temporal and spatial dynamics of suspended sediment, nutrients, and algal biomass in Mark Twain Lake, Missouri. Archiv für Hydrobiologia 135(2):145-178.

Knowlton, M.F., and J.R. Jones. 2006. Temporal variation and assessment of trophic state indicators in Missouri reservoirs: Implication for lake monitoring and management. Lake and Reservoir Management 22:261-271.

Kröger, R.,E.Dibble,J.B.Brandt,J.P. Fleming,T.Huenemann, T. Stubbs, J.D. Prevost, T. Tietjen, K.A. Littlejohn, S.C. Pierce, and M. Spickard. 2011. Spatial and temporal changes in total suspended sediment concentrations in an oxbow lake after implementing agricultural landscape management practices. River Research and Applications doi:10.1002/rra.1579.

Liu, X., X. Zhang, and M. Zhang. 2008. Major factors influencing the efficacy of vegetated buffers on sediment trapping:A review and analysis. Journal of Environmental Quality 37:1667-1674.

Locke, M.A. 2004. Mississippi Delta Management Systems Evaluation Area: Overview of water quality issues on a watershed scale. In Water quality assessments in the Mississippi Delta: Regional solutions, national scope, eds. M.T. Nett, M.A. Locke, and D.A. Pennington, 1-15.ACS Symposium Ser. 877.

Locke, M.A., S.S. Knight, S. Smith, R.F. Cullum, R.M Zablotowicz, Y. Yuan, and R.L. Bingner. 2008. Environmental quality research in the Beasley Lake watershed, 1995-2007: Succession from conventional to conservation practices. Journal of Soil and Water Conservation 63:430-442 doi:10.2489/jswc.63.6.430.

Makarewicz, J.C., T.W. Lewis, I. Bosch, M.R. Noll, N. Herendeen, R.D. Simon, J. Zollweg, and A. Vodacek. 2009. The impact of agricultural best management practices on downstream systems: Soil loss and nutrient chemistry and flux to Conesus Lake, New York, USA. Journal of Great Lakes Research 35:23-36.

Meador, M.R., and R.M. Goldstein. 2003. Assessing water quality at large geographic scales: Relations among land use, water physicochemistry, riparian condition, and fish community structure. Environmental Management 31:504-517.

Nagy, C.R., B.B. Lockaby, B. Helms, L. Kalin, and D. Stoeckel. 2011. Water resources and land use and cover in a humid region: The Southeastern United States. Journal of Environmental Quality 40:867-878.

Renwick, W.H., M.J. Vanni, Q. Zhang, and J. Patton. 2008 Water quality trends and changing agricultural practices in a Midwest U.S. watershed, 1994-2006. Journal of Environmental Quality 37:1862-1874.
Robinson, A.R. 1971. Sediment: our greatest pollutant? Journal of the American Society of Agricultural Engineers 53:406-408.

Roozen, F.C.J.M., G.J. Van Geest, B.W. Ibelings, R. Roijackers, M. Scheffer, and A.D. Buijse. 2003. Lake age and water level affect the turbidity of floodplain lakes along the lower Rhine. Freshwater Biology 48:519-531.

Scheffer, M. 2004. Ecology of Shallow Lakes. Boston, MA: Kluwer Academic Publications.

Schreiber, J.D., R.A. Rebich, and C.M. Cooper. 2001. Dynamics of diffuse pollution from US southern watersheds. Water Research 35:2534-2542.

Steel, R.G.D., J.H. Torrie, and D.A. Dickey. 1997. Principles and Procedures of Statistics: A Biometrical Approach, 3rd ed. New York, NY:McGraw-Hill, Sutherland, A.B., and J.L. Meyer. 2007. Effects of increased suspended sediment on growth rate and gill condition of two southern Appalachian minnows. Environmental Biology of Fishes 80:389-403.

Torremorell, A., J. Bustigorry, R. Escaray, and H.E. Zagarese. 2007. Seasonal dynamics of a large, shallow lake, laguna Chascomús: The role of light limitation and other physical variables. Limnologica 37:100-108.

Tuppad, P., S. Chinnasamy, and R. Srinivasan. 2010. Assessing BMP effectiveness: Multiprocedure analysis of observed water quality data. Environmental Monitoring and Assessment 170:315-329.

USEPA (Environmental Protection Agency). 2005. Protecting water quality from agricultural runoff. EPA 841-F-05-001 Washington, DC.

Yuan, Y., M.A. Locke, and R.L. Bingner. 2008. Annualized agricultural non-point source model application for Mississippi Delta Beasley Lake watershed conservation practice assessment. Journal of Soil and Water Conservation 63:542-551 doi:10.2489/jswc.63.6.542.

Zablotowicz, R.M., M.A. Locke, L.J. Krutz, R.N. Lerch, R.E. Lizotte, S.S. Knight, R.E. Gordon, and R.W. Steinriede. 2006. Influence of watershed system management on herbicide concentrations in Mississippi Delta oxbow lakes. Science of the Total Environment 370:552-560.

Zablotowicz, R.M., P.V. Zimba, M.A. Locke, R.E. Lizotte, S.S. Knight, and R.E. Gordon. 2010. Effects of land management practices on water quality in Mississippi Delta oxbow lakes: Biochemical and microbiological aspects. Agriculture, Ecosystems \& Environment 139:214-223

Zeimen, M.B., K.A. Janssen, D.W. Sweeney, G.M. Pierzynski, K.R. Mankin, D.L. Devlin, D.L. Regehr, M.R. Langemeier, and K.A. McVay. 2006. Combining management practices to reduce sediment, nutrients, and herbicides in runoff. Journal of Soil and Water Conservation 61:258-267.

Zeng, X., and T.C. Rasmussen. 2005. Multivariate statistical characterization of water quality in Lake Lanier, Georgia, USA. Journal of Environmental Quality 34:1980-1991. 